\title{
Differences in Intensity and Specificity of Hypersensitive Response Induction in Nicotiana spp. by INF1, INF2A, and INF2B of Phytophthora infestans
}

\author{
Edgar Huitema, ${ }^{1}$ Vivianne G. A. A. Vleeshouwers, ${ }^{2}$ Cahit Cakir, ${ }^{1}$ Sophien Kamoun, ${ }^{1,2}$ and Francine \\ Govers $^{2}$ \\ ${ }^{1}$ Department of Plant Pathology, The Ohio State University, Ohio Agricultural Research and Development Center, Wooster, \\ U.S.A.; ${ }^{2}$ Laboratory of Phytopathology, Wageningen University, The Netherlands
}

Submitted 19 August 2004. Accepted 11 November 2004.

Elicitins form a family of structurally related proteins that induce the hypersensitive response (HR) in plants, particularly Nicotiana spp. The elicitin family is composed of several classes. Most species of the plant-pathogenic oomycete genus Phytophthora produce the well-characterized 10-kDa canonical elicitins (class I), such as INF1 of the potato and tomato pathogen Phytophthora infestans. Two genes, inf $2 A$ and $\inf 2 B$, encoding a distinct class (class III) of elicitinlike proteins, also occur in $P$. infestans. Unlike secreted class I elicitins, class III elicitins are thought to be cell-surface-anchored polypeptides. Molecular characterization of the inf 2 genes indicated that they are widespread in Phytophthora spp. and occur as a small gene family. In addition, Southern blot and Northern blot hybridizations using gene-specific probes showed that inf $2 A$ and inf $2 B$ genes and transcripts can be detected in 17 different $P$. infestans isolates. Functional secreted expression in plant cells of the elicitin domain of the infl and inf 2 genes was conducted using a binary Potato virus $X$ (PVX) vector (agroinfection) and Agrobacterium tumefaciens transient transformation assays (agroinfiltration), and resulted in HR-like necrotic symptoms and induction of defense response genes in tobacco. However, comparative analyses of elicitor activity of INF1, INF2A, and INF2B revealed significant differences in intensity, specificity, and consistency of $H R$ induction. Whereas INF1 induced the HR in Nicotiana benthamiana, INF2A induced weak symptoms and INF2B induced no symptoms on this plant. Nonetheless, similar to INF1, HR induction by INF2A in $N$. benthamiana required the ubiquitin ligase-associated protein SGT1. Overall, these results suggest that variation in the resistance of Nicotiana spp. to $P$. infestans is shadowed by variation in the response to INF elicitins. The ability of tobacco, but not $N$. benthamiana, to respond to INF2B could explain differences in resistance to $P$. infestans observed for these two species.

Specific recognition events are well established as the functional basis of numerous incompatible (resistance) interactions between plants and pathogens, particularly those occurring at the subspecific or varietal level (race- or cultivar-specific resistance). Recognition is defined by the direct or indirect perception of pathogen signal molecules by plant receptors (Dangl and Jones 2001; Staskawicz et al. 1995). The pathogen signal

Corresponding author: S. Kamoun; Telephone: 330-263 3847; Fax: 330263 3841; E-mail: kamoun.1@ osu.edu molecules commonly are referred to as elicitors, encoded by avirulence $(A v r)$ genes, whereas the plant receptors are the resistance proteins encoded by $R$ genes. Recognition results in the induction of signal transduction pathways leading to the expression of complex defense responses, including the hypersensitive response (HR), a form of programmed cell death often associated with disease resistance in plants (Dangl et al. 1996). Numerous examples of race- or cultivar-specific interactions follow the $A v r-R$ gene model; however, the extent to which recognition events are involved in incompatible interactions occurring at the species or genus level (nonhost resistance) remains unclear (Heath 2000; Kamoun 2001; Kamoun et al. 1999c).

The oomycete plant pathogen Phytophthora infestans causes late blight, a devastating and re-emerging disease of potato and tomato (Birch and Whisson 2001; Fry and Goodwin 1997a,b; Schiermeier 2001; Shattock 2002; Smart and Fry 2001). In contrast to host plants, nonhosts, such as tobacco and other species of the genus Nicotiana, typically are resistant to $P$. infestans. Cytological analyses of leaves of several Nicotiana spp. inoculated with $P$. infestans showed that penetration of epidermal cells always occurred (Kamoun et al. 1998c). This was followed by the HR that varied between different Nicotiana spp. in timing, severity, and number of affected cells. In Nicotiana tabacum (tobacco), P. infestans was blocked early in the infection following penetration of epidermal cells, and secondary intercellular hyphae were not observed. In contrast, in $N$. benthamiana, secondary hyphae with haustoria were formed and some level of mesophyll colonization occurred. The plant response reached a climax 3 days post inoculation with clusters of HR cells engulfing the invading hyphae. These observations suggest that several layers of resistance to $P$. infestans occur with various degrees of effectiveness in the different Nicotiana species (Kamoun 2001; Kamoun et al. 1998b; Kamoun et al. 1999c).

P. infestans and other Phytophthora spp. express a family of structurally related extracellular proteins, known as elicitins, which induce the HR and other biochemical changes associated with defense responses in Nicotiana spp. but not in potato and tomato (Kamoun et al. 1993, 1997a; Ponchet et al. 1999; Ricci et al. 1989; Sasabe et al. 2000). P. infestans strains deficient in the elicitin INF1 induced disease lesions in $N$. benthamiana, suggesting that INF1 conditions resistance in this species (Kamoun et al. 1998b). In contrast, INF1-deficient strains remained unable to infect other Nicotiana spp., such as tobacco. In this case, tobacco was hypothesized to react to additional elicitors, perhaps other elicitin-like proteins (Kamoun 
2001; Kamoun et al. 1998b, 1999c). Indeed, in P. infestans, a complex set of elicitin-like genes was isolated using polymerase chain reaction (PCR) amplification with degenerate primers, low stringency hybridizations, and random sequencing of cDNAs (Fabritius et al. 2002; Kamoun et al. 1997a, and b, 1999b). In total, eight elicitin and elicitin-like genes (termed inf genes) have been reported so far in $P$. infestans. All these genes encode putative extracellular proteins that share the 98amino-acid (aa) elicitin domain corresponding to the mature class I elicitins, such as INF1. This domain is defined as the elicitin domain in many protein motif databases, such as pfam (PF00964) (Bateman et al. 2002) and InterPro (IPR002200) (Mulder et al. 2003). Six inf genes (inf2A, inf2B, inf5, inf6, inf7, and $M-25$ ) encode predicted proteins with a C-terminal domain in addition to the $\mathrm{N}$-terminal elicitin domain. Sequence analysis of these $\mathrm{C}$-terminal domains revealed a high frequency of serine, threonine, alanine, and proline. The amino-acid composition and the distribution of these four residues indicated the likely occurrence of clusters of $O$-linked glycosylation sites (Kamoun et al. 1997a). These proteins are likely to form a "lollipop on a stick" structure in which the $O$-glycosylated domain forms an extended rod that anchors the protein to the cell wall, leaving the extracellular $\mathrm{N}$-terminal domain exposed

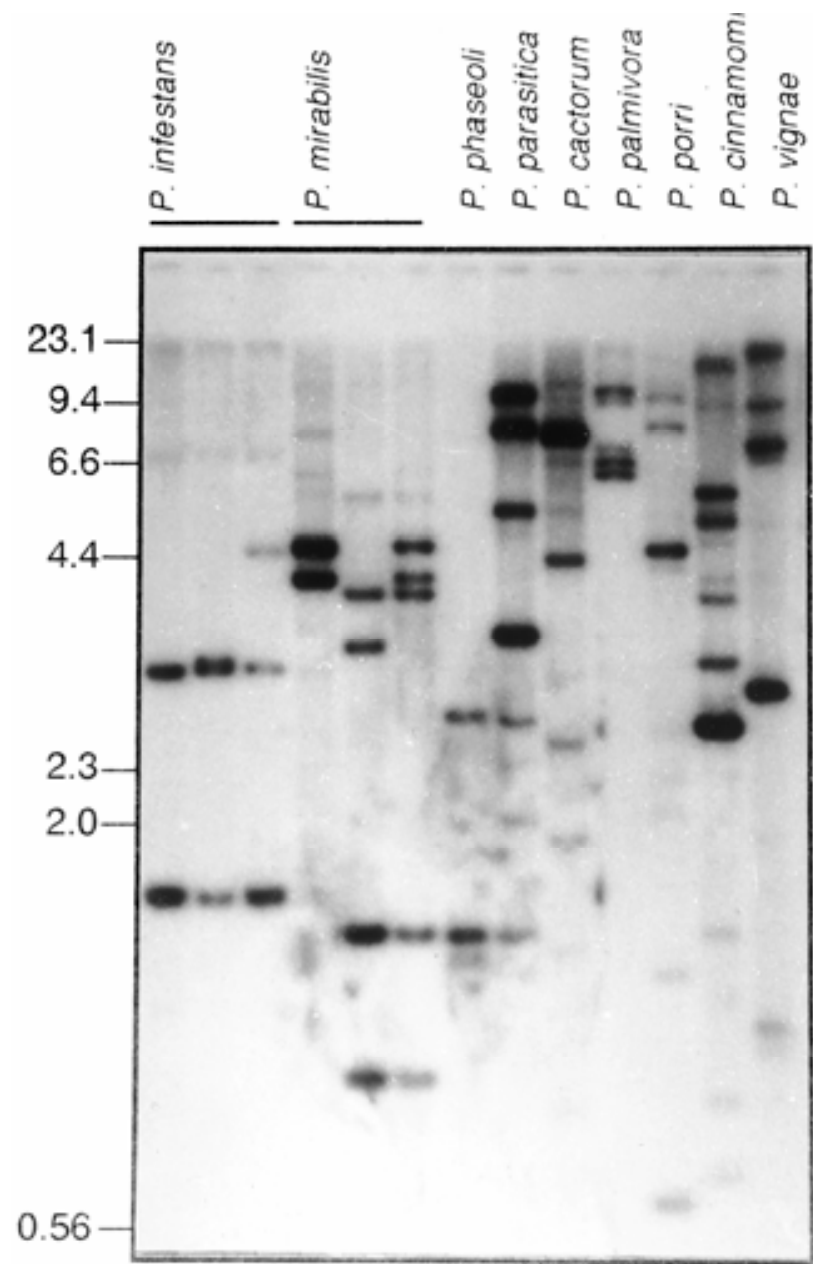

Fig. 1. Occurrence of inf2 sequences in Phytophthora spp. DNA blot containing $20 \mu \mathrm{m}$ of HindIII-digested total DNA from 13 isolates representing nine Phytophthora spp. (i.e., P. infestans isolates 88069, 90128, and IPO-0; P. mirabilis CBS 678.85, CBS136.86, and CBS150.88; P. phaseoli CBS 556.88; P. parasitica 18; P. cactorum 436; P. palmivora 10; P. porri HH; P. cinnamomi 2 ; and P. vignae 20853) was hybridized with a probe from the elicitin domain of inf 2 which hybridizes to both $\inf 2 A$ and $\inf 2 B$. Molecular marker sizes are shown on the left in kilobases. on the cell surface (Jentoft 1990). Therefore, these atypical INF proteins may be surface- or cell-wall-associated glycoproteins that could interact with plant cells during infection.

The intrinsic biological function of elicitins in Phytophthora spp. has long remained a mystery. Conclusive evidence finally emerged when it was demonstrated that class I elicitins bind sterols, such as ergosterol, and function as sterol-carrier proteins (Boissy et al. 1999; Mikes et al. 1997, 1998; Vauthrin et al. 1999). Consequently, elicitins were hypothesized as having a biological function of essential importance to Phytophthora spp. because they cannot synthesize sterols and must assimilate them from external sources (Hendrix 1970). In addition, phospholipase activity was assigned to elicitin-like proteins from $P$. capsici with significant similarity to INF5 and INF6 (Nespoulous et al. 1999), suggesting a general lipid binding or processing role for the various members of the elicitin family (Osman et al. 2001a). Other work by Osman and associates (2001b) using elicitin mutants altered in sterol binding revealed that sterol loading is important for specific-binding to a plasma membrane receptor and induction of the HR in tobacco. More recently, another gene with similarity to elicitins, $M-25$, was reported to be induced during mating in $P$. infestans (Fabritius et al. 2002).

In this article, we report the molecular and functional characterization of $P$. infestans genes encoding the class III elicitinlike INF2A and INF2B proteins (Kamoun et al. 1997a). We examined the occurrence of inf 2 sequences in $P$. infestans and other Phytophthora spp., the full genomic sequence of the inf $2 A$ gene, and the expression of the inf 2 genes in various isolates of $P$. infestans and during the $P$. infestans-tomato interaction. In addition, we compared INF2 proteins to the well-characterized INF1 elicitin for their elicitor activity using both the binary Potato virus X (PVX) expression system (agroinfection) and Agrobacterium tumefaciens transient transformation assays (agroinfiltration). Last, we characterized the defense responses induced by INF2 in $N$. tabacum and showed that, similar to INF1, necrosis induction by INF2A in $N$. benthamiana requires the ubiquitin ligase-associated protein SGT1. These experiments revealed significant differences in intensity, specificity, and consistency of HR induction among INF1, INF2A, and INF2B. We found that tobacco, but not $N$. benthamiana, responded to INF2B. This could explain differences in resistance to $P$. infestans observed for these two species.

\section{RESULTS}

Occurrence of inf 2 sequences in Phytophthora spp.

The products of the inf $2 A$ and inf $2 B$ genes form a distinct class of elicitins previously designated class III (Kamoun et al. 1997a). In order to assess the occurrence and distribution of sequences similar to inf 2 across a range of Phytophthora spp., total DNA from 13 isolates representing nine Phytophthora spp. was hybridized at low stringency with a probe from the elicitin domain of inf2 (Fig. 1). This inf2 probe hybridized to both inf $2 A$ and inf $2 B$; however, under similar hybridization conditions, no cross-hybridization between this probe and other $P$. infestans inf elicitin genes was observed. All tested isolates of the examined Phytophthora spp. appeared to contain from two to eight HindIII bands homologous to the inf2 elicitin domain (Fig. 1). Similar hybridization experiments on total DNA from four additional oomycete species (Pythium aphanidermatum, isolate 28; P. sylvaticum, 933; Aphanomyces leavis, 465.64; and Saprolegnia ferax, G-1295) did not yield any detectable signals (data not shown). Therefore, it appears that inf2-like elicitin genes may occur as a small genus-specific gene family and are conserved in all tested species of Phytophthora. 
Isolation and characterization of $\inf 2 A$ genomic region.

To determine the genomic structure of the inf $2 A$ gene, a גEMBL3 genomic library of Phytophthora infestans 88069 (Pieterse et al. 1993) was hybridized with the inf2 probe. A total of five hybridizing clones were identified. DNA from these clones was digested with HindIII, blotted, and hybridized with the inf 2 probe (data not shown). Three of the clones contained a 1.7-kb HindIII hybridizing band that co-migrated with one of the bands revealed on the total DNA blot (Fig. 1, lane 1). The other two positive clones were not reconfirmed in subsequent hybridizations. The 1.7-kb HindIII fragment was subcloned into pBluescript SK- and fully sequenced using a primer walking approach. The nucleotide sequence revealed a 1,654-bp HindIII fragment (GenBank accession number AY693804) and was found to contain a 558-bp open reading frame (ORF) that perfectly matched the ORF in the inf $2 A$ cDNA sequence, suggesting that, similar to other elicitin genes from Phytophthora spp., the inf $2 A$ gene does not contain introns. Examination of the nucleotide sequence upstream of the ORF revealed, at position -50 relative to the ATG start codon, sequence TCTCATT CTACAATTT, similar to the oomycete transcriptional start site motif (Kamoun 2003; McLeod et al. 2004; Pieterse et al. 1993). Downstream of the ORF, the 51-bp sequence that corresponded to the $3^{\prime}$ untranslated region contained a potential polyadenylation signal ATTAAA, located $18 \mathrm{bp}$ downstream of the TAA stop codon. No significant similarities between the noncoding sequences of the inf $2 A$ gene and the noncoding sequences of other elicitin genes were noted. In this screening, no genomic clone corresponding to inf $2 B$ was recovered from the genomic library.

\section{Occurrence of inf $2 A$ and inf $2 B$ in $P$. infestans.}

To determine whether the inf $2 A$ and $\inf 2 B$ genes are conserved in P. infestans, BamHI-digested total DNA from a collection of 16 isolates of $P$. infestans (Kamoun et al. 1998a) was sequentially hybridized with gene-specific probes containing $3^{\prime}$ end portions of the inf $2 A$ and inf $2 B$ cDNAs as well as a specific $3^{\prime}$ end probe of the infl cDNA (Kamoun et al. 1997a) (Fig. 2). All probes lack a BamHI site. One to two genomic copies for each of the inf $2 A$ and $\inf 2 B$ genes could be detected in all $16 P$. infestans isolates examined, whereas a single infl band was revealed. In some isolates, both the inf $2 A$ and inf $2 B$ probes revealed bands with lower intensity. No cross-hybridization was noted between the inf 2 probes and other inf elicitin genes under the hybridization conditions used; therefore, we expected these bands to contain inf2-like sequences. However, we cannot conclude at this stage whether the faint bands correspond to additional alleles or gene copies of inf 2 or to pseudogene sequences. GE900083, an isolate from Germany, lacked the strongly hybridizing inf $2 \mathrm{~A}$ band observed in all other isolates.

\section{inf $2 A$ and inf $2 B$ mRNAs are produced \\ by all tested $P$. infestans isolates.}

A small number of field isolates of $P$. infestans are deficient in mRNA of the elicitin gene infl and in INF1 protein (Kamoun et al. 1998a). To determine whether these and other isolates show altered levels of inf $2 A$ and $\inf 2 B$ mRNA, total RNA from the 16 isolates of $P$. infestans examined in Figure 2, as well as $P$. infestans 88069 , was sequentially hybridized with the inf $2 A$, inf $2 B$, and infl gene-specific probes (Fig. 3). All tested isolates showed detectable levels of inf $2 A$ and inf $2 B$ mRNA, suggesting that inf $2 \mathrm{mRNAs}$ are produced by all tested $P$. infestans isolates, including the two isolates DDR7602 and DDR7702 that previously were shown to lack infl mRNA (Kamoun et al. 1998a). However, in this experiment, levels of inf 2 mRNA were variable between the examined isolates. GE900083, the isolate that lacked the major inf $2 A$ band in the Southern blot analyses, also produced a signal for inf $2 A$ mRNA.

\section{inf $2 A$ and inf $2 B$ are expressed}

during the $P$. infestans-tomato interaction.

We determined the expression profiles of inf $2 A$ and inf $2 B$ genes during a time course infection of tomato by $P$. infestans using semi-quantitative reverse transcription (RT)-PCR. Genespecific primers for inf $2 A$, inf $2 B$, infl, and the constitutive elongation factor $2-\alpha(e f 2 \alpha)$ gene were used. Expression of inf $2 A$ was detected 3 days after inoculation, whereas expression of infl and inf $2 B$ was observed as early as 1 day after inoculation (Fig. 4). In contrast to infl, which reached the highest levels of expression at the latest time point (day 4), inf $2 A$ expression peaked at day 3 and $\inf 2 B$ at days 3 and 4 . These results show that both inf 2 genes are expressed during $P$. infestans colonization of tomato.

\section{Heterologous expression of inf $2 A$ and inf $2 B$ in plants using agroinfection of PVX.}

To express the inf 2 genes in plant cells and examine their elicitor activity, we first used the PVX system, which proved effective in assaying the HR-inducing activity of the infl gene (Kamoun et al. 1999a; Qutob et al. 2002; Torto et al. 2003). A fusion between the signal sequence of the $P R-1 a$ gene of tobacco (Hammond-Kosack et al. 1995) and the sequence of the 98-aa elicitin domain of INF2A and INF2B (Kamoun et al. 1997a) was cloned into in the binary PVX vector pGR106 (Lu et al. 2003). Two recombinant plasmids, pGR106-INF2A and pGR106-INF2B, were confirmed to contain the correct inserts by DNA sequencing and subsequently were introduced into Agrobacterium tumefaciens to allow delivery of PVX in plants via agroinfection. A. tumefaciens strains carrying the pGR106-

\section{6}

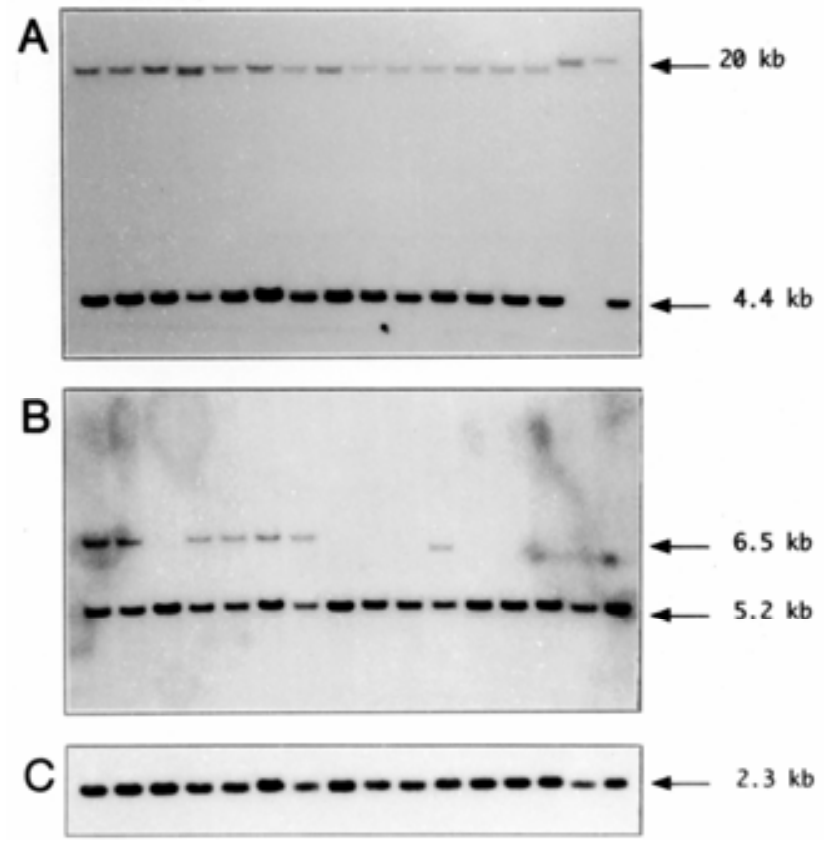

Fig. 2. Occurrence of the $\inf 2 A$, inf $2 B$, and infl sequences in isolates of Phytophthora infestans. DNA blot containing BamHI-digested total DNA from $P$. infestans isolates (1) DDR7601, (2) DDR7602, (3) DDR7702, (4) GER7401, (5) GER8451, (6) GER8501, (7) GER8601, (8) 46210, (9) 66006, (10) 68308, (11) 70001, (12) UK7225, (13) UK7818, (14) IT8001, (15) GE900083, and (16) GE900089 (Kamoun et al. 1998a) was hybridized with specific probes from the $\mathbf{A}$, inf $2 A, \mathbf{B}$, inf $2 B$, and $\mathbf{C}$, infl genes. The approximate sizes of the hybridizing bands are shown on the right in kilobases. 
INF2 constructs were inoculated side-by-side on mature leaves of $N$. tabacum (tobacco, cv. Xanthi) and N. benthamiana and compared with a strain carrying a pGR106 derivative expressing the PRla::infl construct (pGR106-INF1) (Fig. 5). In tobacco, all three strains induced rapid symptoms consisting of localized HR-like necrotic lesions. In contrast, $N$. benthamiana leaves challenged with the pGR106-INF1 and pGR106-INF2A strains exhibited localized necrotic lesions, whereas the pGR106INF2B strain failed to cause visible symptoms (Fig. 5).

In addition to these qualitative differences, there was significant variation in the efficiency and extent of elicitation of necrotic symptoms between the elicitins (Table 1). On responding plants, the pGR106-INF1 and pGR106-INF2B strains were very consistent, resulting in necrotic symptoms in at least $93 \%$ of the inoculation sites (Table 1). In contrast, the pGR106INF2A strain was poorly efficient, resulting in necrotic symptoms in 36 and $70 \%$ of the inoculation sites on tobacco and $N$. benthamiana, respectively. Also, the pGR106-INF2A strain induced smaller necrotic lesions averaging 0.9 and $1.9 \mathrm{~mm}$ in tobacco and $N$. benthamiana, respectively, whereas the pGR106-INF1 and pGR106-INF2B strains induced lesions ranging from 3.2 to $5.8 \mathrm{~mm}$ in size on responding plants. Inoculations of all plants with mock and vector controls never resulted in necrotic symptoms.

To determine the significance of our observations, statistical analysis was performed on necrotic lesion size data. Analysis of variance using the generalized linear models procedure and subsequent $t$ test comparisons indicated significant differences between the elicitors tested on both $N$. benthamiana and $N$. $t a$ bacum (Table 1).

To confirm the lack of response of $N$. benthamiana to INF2B, we repeated the agroinfection inoculations on individual young seedlings, an assay that is more sensitive than mature leaf inoculations because it allows systemic spread of the recombinant PVX and enhanced accumulation of the inf transcripts (Torto et al. 2003). Inoculation of $N$. benthamiana seedlings with the pGR106-INF2B strain consistently failed to result in any necrotic symptoms and always resulted in mosaic virus symptoms similar to those obtained with the empty vector strain. In contrast, both the pGR106-INF1 and pGR106-INF2A strains induced necrotic lesions starting 6 days after inoculation (data not shown).

Together, these results show that, unlike tobacco, $N$. benthamiana does not respond to INF2B, and suggest that INF2A may constitute a weaker HR elicitor than INF1 and INF2B.

\section{Heterologous expression of inf $2 A$ and $i n f 2 B$ in plants using agroinfiltration.}

To validate the elicitor activity of INF2A and INF2B and further compare it to INF1, we used agroinfiltration to express the three inf genes in plant cells. The PRla::inf gene fusions were transferred to a Cauliflower mosaic virus (CaMV) $35 \mathrm{~S}$ promoter and a potato proteinase-II terminator cassette in a $\mathrm{T}$ DNA binary vector as described in the methods. A. tumefaciens

\section{$12 \begin{array}{llllllll}1 & 4 & 6 & 78 & 9 & 1011 & 121314151617\end{array}$}

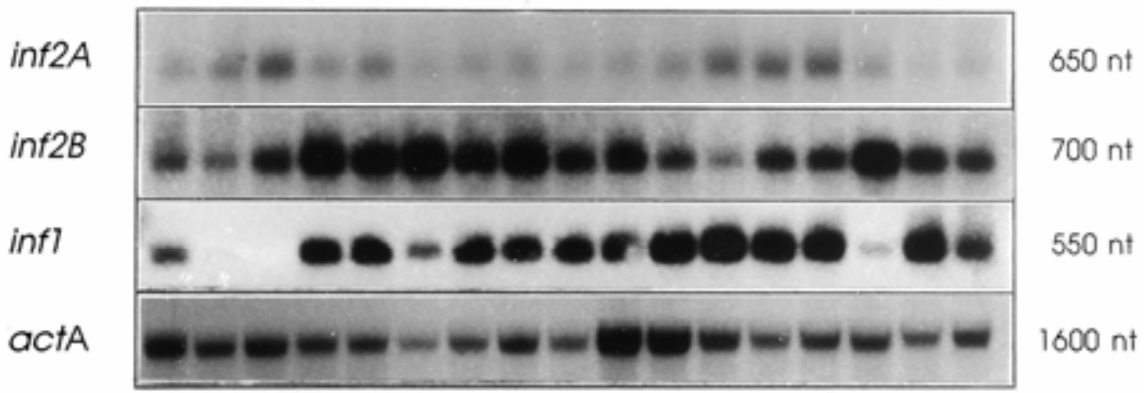

Fig. 3. Occurrence of the inf2A, inf2B, and inf1 mRNA in isolates of Phytophthora infestans. RNA blots containing total RNA from DDR7601 (1), DDR7602 (2), DDR7702 (3), GER7401 (4), GER8451 (5), GER8501 (6), GER8601 (7), 46210 (8), 66006 (9), 68308 (10), 70001 (11), UK7225 (12), UK7818 (13), IT8001 (14), GE900083 (15), GE900089 (16) and 88069 (17) were hybridized with specific probes from the inf2A, inf2B, inf1, and actA genes. The approximate sizes of the inf and actA transcripts are shown on the right.

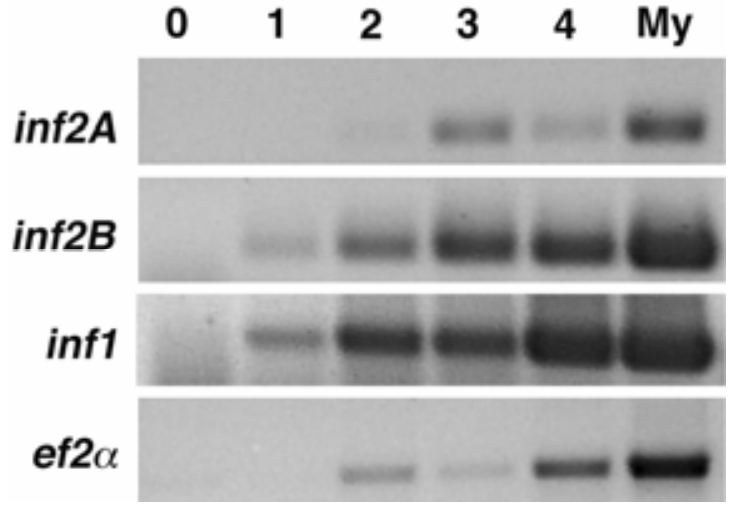

Fig. 4. Expression of Phytophthora infestans inf $2 A$, inf $2 B$, and infl during infection of tomato. Total RNA from $P$. infestans-infected leaves of tomato $0,1,2,3$, and 4 days after inoculation, and $P$. infestans mycelium (My) grown in a synthetic medium were used in reverse-transcription polymerase chain reaction amplifications as described in the text. Amplification of the $P$. infestans elongation factor 2 (ef $2 \alpha)$ was used as a control to determine the integrity of the RNA.

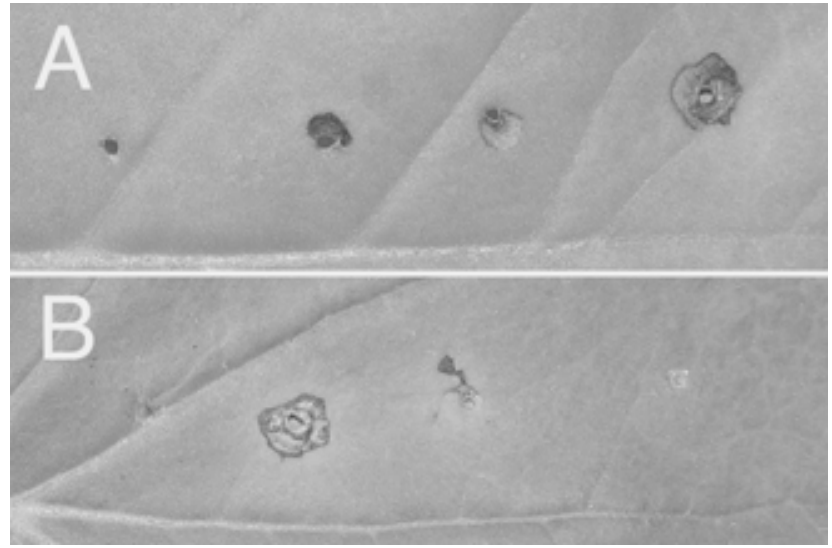

Fig. 5. Agroinfection assays. Symptoms observed on A, Nicotiana tabacum (tobacco) and B, N. benthamiana leaves after inoculation with Agrobacterium tumefaciens containing the binary Potato virus $X$ (PVX) vector expressing Phytophthora infestans inf genes. Inoculated leaves were photographed 10 days after inoculation with A. tumefaciens containing, from left to right, the binary PVX vector pGR106, pGR106-INF1, pGR106-INF2A, and pGR106-INF2B. 
strains carrying the various p35S-INF constructs were infiltrated into young and fully expanded leaves of N. tabacum (cv. Xanthi) and $N$. benthamiana (Fig. 6). As negative controls, $A$. tumefaciens carrying pGUSi, which contains a $\beta$-glucuronidase gene interrupted by an intron (Hood et al. 1993), as well as buffer solutions were used. In $N$. tabacum, confluent necrosis in the entire infiltrated areas appeared 2 days following infiltration of the p35S-INF2A-, p35S-INF2B-, and p35SINF1-carrying strains. In contrast, in $N$. benthamiana, only the A. tumefaciens strain carrying p35S-INF1 consistently induced necrosis, generally starting at 3 to 4 days after infiltration. In repeated side-by-side infiltrations of $N$. benthamiana leaves with the p35S-INF1 and p35S-INF2 strains, the p35S-INF2B strain did not induce necrotic symptoms. However, occasionally, the p35S-INF2A construct caused necrosis in N. benthamiana. The negative control strain carrying pGUSi and the buffer solutions did not induce necrosis in both tobacco and $N$. benthamiana. These results confirm that $N$. benthamiana does not respond to INF2B and that INF2A may act as a weaker HR elicitor on this plant species.
INF2B induces PRIa and Bgl2 expression in tobacco.

To assess whether the necrotic response elicited by the INF2 proteins is associated with the induction of plant defense response genes, we wound inoculated leaves of a transgenic tobacco line carrying the GUS reporter gene driven by the promoter of the pathogenesis-related genes Bgl2 (PR2) (Livne et al. 1997) with A. tumefaciens strains carrying pGR106-INF1, pGR106-INF2A, and pGR106-INF2B (Fig. 7A). Negative controls consisted of the A. tumefaciens strain carrying the vector pGR106 and mock inoculations. GUS histochemical staining of inoculated leaves showed some blue staining in the pGR106 treatment, suggesting that the vector strain induces low levels of Bgl2 expression. However, the pGR106-INF1 strain and, particularly, the pGR106-INF2B strain consistently induced stronger and larger areas of GUS staining than the vector control in 31 and $38 \%$ of the inoculation sites, respectively. The pGR106-INF2A strain did not consistently induce different GUS staining than the controls.

We also performed Northern blot analyses using RNA isolated from leaf discs surrounding inoculation sites of a non-

Table 1. Recombinant Potato virus $X$ expressing inf elicitin genes induce variable levels of necrosis on Nicotiana tabacum and $N$. benthamiana ${ }^{z}$

\begin{tabular}{|c|c|c|c|c|}
\hline \multirow[b]{2}{*}{ Construct } & \multicolumn{2}{|c|}{ N. tabacum } & \multicolumn{2}{|c|}{ N. benthamiana } \\
\hline & Inoculations with necrosis (\%) & Necrotic lesion size $(\mathbf{m m})$ & Inoculations with necrosis (\%) & Necrotic lesion size $(\mathrm{mm})$ \\
\hline Mock & 0 & 0 & 0 & 0 \\
\hline pGR106 & 0 & 0 & 0 & 0 \\
\hline pGR106-INF1 & 93 & $3.2 \mathrm{a}$ & 100 & $5.8 \mathrm{a}$ \\
\hline pGR106-INF2A & 36 & $0.9 \mathrm{~b}$ & 70 & $1.9 \mathrm{~b}$ \\
\hline pGR106-INF2B & 100 & $4.9 \mathrm{c}$ & 0 & $0 \mathrm{c}$ \\
\hline
\end{tabular}

${ }^{2}$ Results were obtained from one representative experiment. A total of 14 inoculation sites were analyzed for $N$. tabacum and 20 for $N$. benthamiana. Lesion size data was used in $t$ test comparisons of treatments $(P=0.01)$. Mean separations were performed within each species. Results followed by different letters are significantly different.
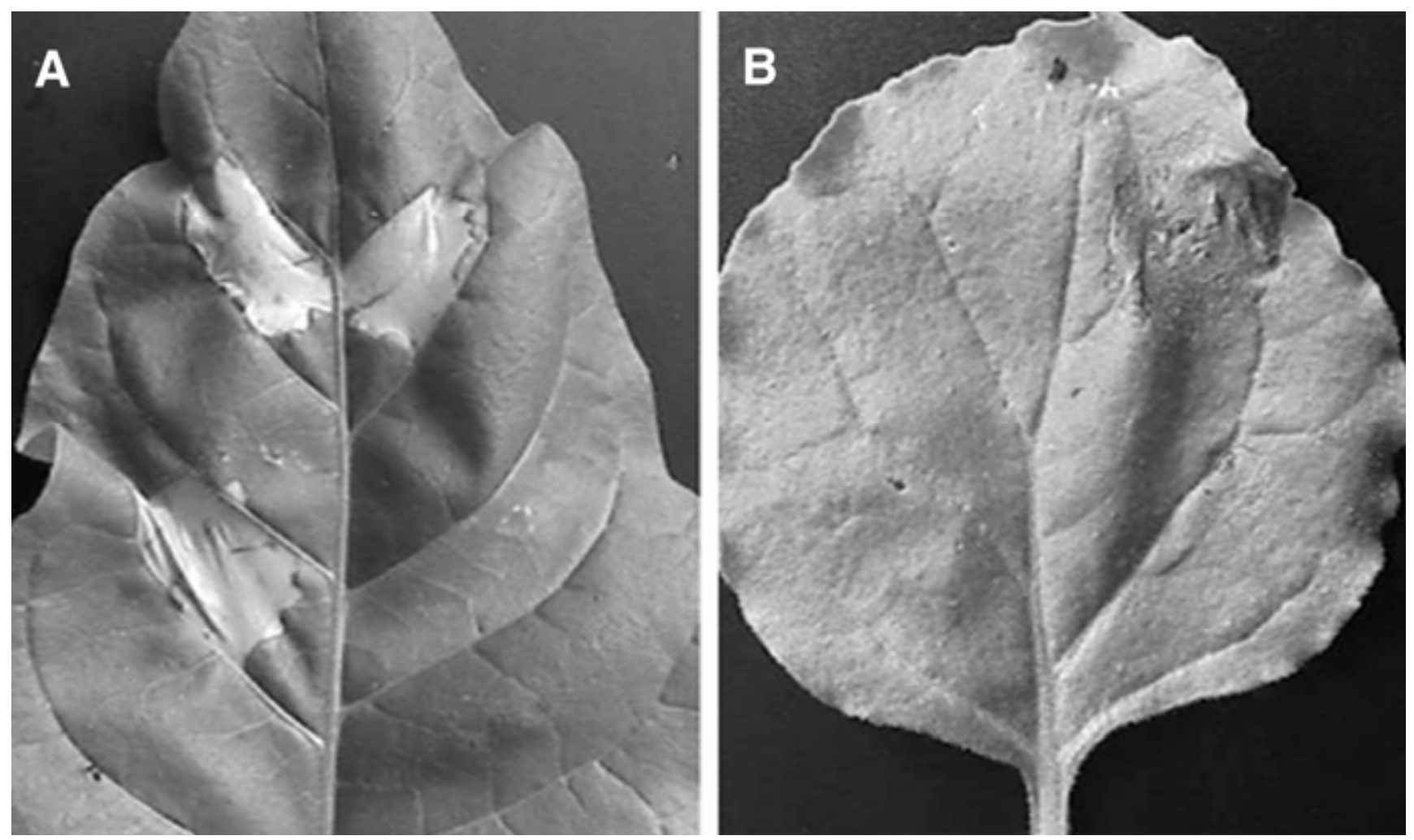

Fig. 6. Agroinfiltration assays. Symptoms observed on Nicotiana tabacum (tobacco) (left panel) and N. benthamiana (right panel) leaves after infiltration with Agrobacterium tumefaciens containing binary vectors expressing Phytophthora infestans inf genes. Inoculated leaves were photographed 6 days after inoculation with A. tumefaciens containing the binary vector p35S-INF2A (top left section of the leaves), p35S-INF2B (bottom left), p35S-INF1 (top right), and the negative control pGUSi (bottom right). 
transgenic tobacco line using the same treatments as in the Bgl2::GUS experiment (Fig. 7B). Hybridization of the blots with probes of the pathogenesis-related gene PRla and the constitutive gene $\alpha$-tubulin revealed moderate induction of PRla by the vector construct. Nevertheless, both pGR106INF1 and pGR106-INF2B elicited increased levels of PRIa expression. These experiments suggest that, similar to INF1, INF2B induces the expression of the pathogenesis-related genes PRla and Bgl2 in tobacco. However, no significant induction by INF2A could be demonstrated under these experimental conditions.

\section{SGT1 is required for HR elicitation by INF2A.}

Peart and associates (2002) demonstrated that the ubiquitin ligase-associated protein SGT1 is required for HR induction by INF1 in $N$. benthamiana. To test whether response to INF2A also requires SGT1, we used Tobacco rattle virus (TRV) to silence $S G T 1$ in $N$. benthamiana (Huitema et al. 2004; Peart et al. 2002; Ratcliff et al. 2001). For this purpose, we infiltrated young $N$. benthamiana plants (five-leaf stage) with A. tumefaciens strains containing the binary vector pBintra6 (TRV RNA1) mixed with strains carrying the empty pTV00 vector (TRV RNA2) or pTV00:SGT1 (Peart et al. 2002). Three weeks after infiltration, we performed challenge inoculations using agroinfiltration (Fig. 8A) or agroinfection (Fig. 8B) as described above. In both experiments, INF1 consistently induced the HR on plants inoculated with the TRV vector but not on the TRV:SGT1 plants. Similarly, INF2A induced the HR in 20 to $50 \%$ of the inoculations in plants treated with the TRV vector but not on the TRV:SGT1 plants. As noted earlier, INF2B did not induce necrosis in $N$. benthamiana. These results suggest that, similar to INF1, the HR induced by INF2A in $N$. benthamiana is SGT1dependent.

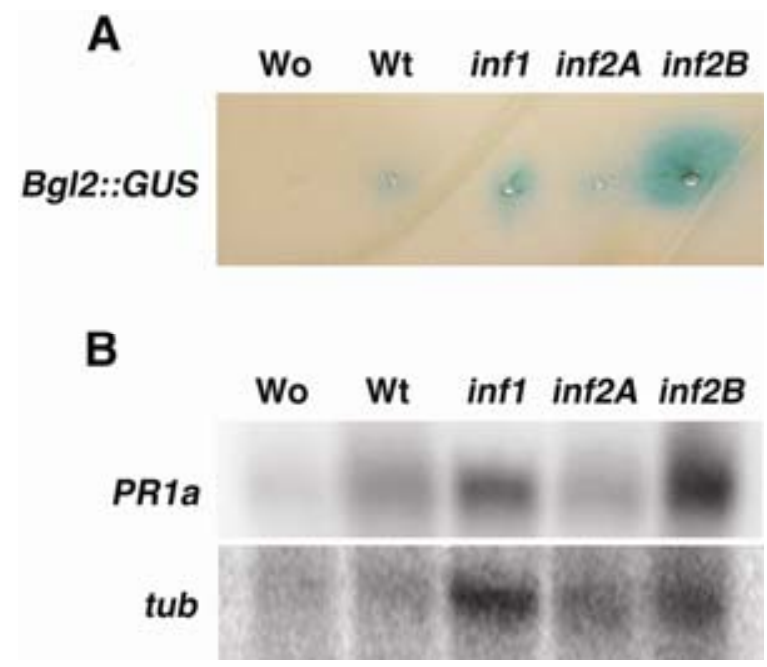

Fig. 7. Induction of defense response genes in tobacco by INF1 and INF2. A, Histochemical GUS assay of a leaf from transgenic tobacco line carrying a Bgl2:GUS construct. The leaf was wound-inoculated with a toothpick only (Wo) as well as with Agrobacterium tumefaciens strains carrying pGR106 (Wt), pGR106-INF1, pGR106-INF2A, and pGR106-INF2B. The picture illustrates a representative leaf stained 8 days after inoculation. B, Northern blot hybridization of RNA isolated from tobacco leaves (cv. Xanthi) that were wound-inoculated with a toothpick only (Wo) or toothpick inoculated with A. tumefaciens strains carrying pGR106 (Wt), pGR106-INF1, pGR106-INF2A, and pGR106INF2B. The blot was hybridized with probes from the defense gene PRla and the constitutive gene $\alpha$-tubulin $(t u b)$. Total RNA was harvested from leaf discs surrounding the inoculation sites immediately after the onset of necrosis. Different leaves were used for the different treatments.

\section{DISCUSSION}

Elicitins form a ubiquitous family of structurally related proteins in Phytophthora spp. In P. infestans, eight elicitin and elicitin-like genes (inf genes) corresponding to distinct classes have been reported (Fabritius et al. 2002; Kamoun et al. 1997a, and b, 1999b). So far, most studies on P. infestans elicitins have focused on the 98-aa canonical elicitin, INF1 (class Ia) (Kamoun et al. 1997a; 1998a, and b, 1999b; Kanzaki et al. 2003; Sasabe et al. 2000; Sharma et al. 2003). In this article, we report the molecular and functional characterization of the inf2 class (class III) of elicitin-like genes from $P$. infestans (Kamoun et al. 1997a). Our main finding is that variation in the resistance of Nicotiana spp. to P. infestans is shadowed by variation in the response to INF elicitins. The ability of tobacco, but not $N$. benthamiana, to respond to INF2B could explain differences in resistance to $P$. infestans observed for these two species.

Despite the rapid accumulation of sequence data from numerous organisms, elicitin-like genes and proteins have been identified only in the oomycete genera, Phytophthora and Pythium. In the genus Phytophthora, production of the $10-\mathrm{kDa}$ class I elicitins is quasi-ubiquitous and has been attributed to more than 30 species so far (Kamoun et al. 1994; Ponchet et al. 1999). The Southern blot hybridizations illustrated in Figure

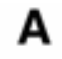

A

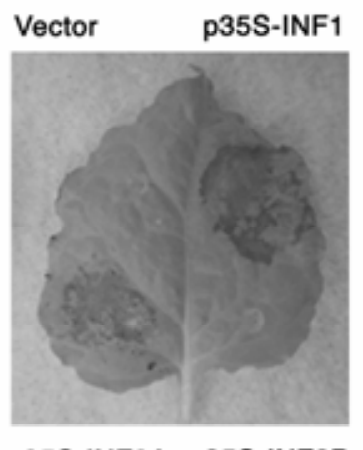

p35S-INF2A p35S-INF2B

\section{TRV::NbSGT1}

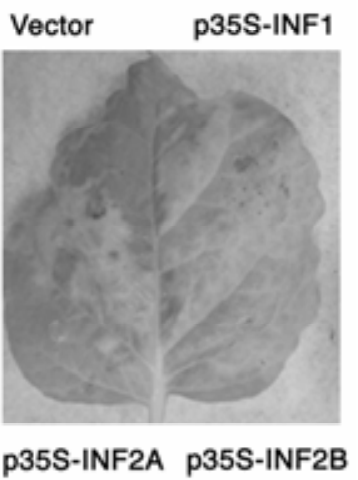

B

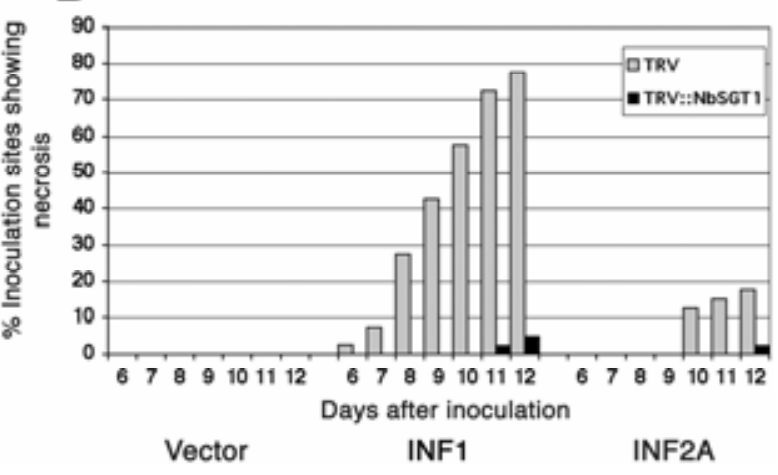

Fig. 8. Symptoms observed in Nicotiana benthamiana silenced for the ubiquitin ligase-associated gene $S G T 1$ following agroinfiltration and Potato virus $X$ (PVX) agroinfection with infl and inf2 constructs. $N$. benthamiana plants were first inoculated with Agrobacterium tumefaciens carrying the Tobacco rattle virus vector (TRV) or a TRV:SGT1 construct (TRV:SGT1), and then challenged after 3 weeks with A, A. tumefaciens carrying vector (top left), p35S-INF1 (top right), p35S-INF2A (bottom left), and p35S-INF2B (bottom right) constructs, or B, A. tumefaciens carrying the binary PVX vector pGR106, pGR106-INF1, and pGR106INF2A. Leaves in panel A were photographed 5 days after the secondary agroinfiltration. The bars in panel B correspond to the percentage of $A$. tumefaciens binary PVX inoculation sites showing the hypersensitive response over time $(n=40)$. 
1 suggest that the inf 2 class of elicitin-like genes is similarly widespread because inf2-like sequences were detected in all nine Phytophthora spp. examined. In addition, we also identified sequences highly similar to inf2 by searching the expressed sequence tag (EST) database of P. sojae (Qutob et al. 2000, 2003). These results indicate that the inf2 class of elicitin-like genes occurs as a small conserved family in Phytophthora spp.

Using Southern blot analyses with gene-specific probes, one to two genomic copies of the $\inf 2 A$ and $\inf 2 B$ genes could be detected in 16 different $P$. infestans isolates. In addition, inf 2 mRNA was ubiquitously present in these $P$. infestans isolates, although at variable levels. The biological basis and significance of this variation remains unclear. The two $P$. infestans isolates previously described as naturally deficient in INF1 production (Kamoun et al. 1998a) were found to produce inf2 mRNA. In addition, infl sense and antisense transformants that showed no detectable levels of infl mRNA (Kamoun et al. $1998 \mathrm{~b}$ ) were found to be unaltered in inf 2 mRNA using Northern blot hybridizations (van West et al. 1999). These results suggest that downregulation of infl mRNA does not correlate with altered levels of inf 2 mRNA.

We monitored gene expression levels of both inf $2 A$ and inf $2 B$ during $P$. infestans - tomato interactions. Semiquantitative RT-PCR experiments revealed that both inf $2 A$ and inf $2 B$ are expressed during infection of tomato, indicating that these proteins are functionally relevant to $P$. infestans pathogenesis. Expression patterns of the inf 2 genes in planta were slightly different from those of infl, which tends to peak late during infection (Kamoun et al. 1997b). However, more precise methods for measuring gene expression need to be applied to confirm these results prior to speculating on their biological implications.

Comparative analyses of elicitor activity of INF1, INF2A, and INF2B using PVX agroinfection and agroinfiltration revealed that, similar to INF1 and other elicitins, INF2A and INF2B induced HR-like symptoms on tobacco. However, using these assays, differences in HR induction were noted among the three elicitors in both tobacco and $N$. benthamiana. A significant difference in specificity of HR induction was obtained for INF2B, which, unlike INF1 and INF2A, failed to induce necrosis on $N$. benthamiana in both assays (Figs. 4 and 5; Table 1). On the other hand, INF2A only occasionally induced the HR in $N$. benthamiana using agroinfiltration, and induced small and inconsistent necrotic lesions using agroinfection (Table 1). These results suggest that expression of inf $2 A$ in $N$. benthamiana via these transient assays may not be efficient enough to consistently result in necrosis. Alternatively, unknown environ- mental or host factors may affect the level of expression or response to INF2A in $N$. benthamiana, resulting in the inconsistent responses. In any case, these results support the view that INF2A is an overall weaker HR elicitor than INF1 and INF2B. This conclusion also is supported by the experiments described in Figure 7 that show that INF2B and INF1 but not INF2A induced the expression of the defense genes PRI $a$ and $B g l 2$ in tobacco. However, the extent to which these differences are significant to natural $P$. infestans-plant interactions remains to be determined.

We determined that the ubiquitin ligase-associated protein SGT1 is required for HR induction by INF2A, as previously shown for INF1 (Peart et al. 2002). SGT1 has emerged as a central player in $R$ gene-mediated HR signaling in plants as diverse as barley, Arabidopsis thaliana, and N. benthamiana (Peart et al. 2002; Shirasu and Schulze-Lefert 2003; Tör et al. 2003). Using TRV-mediated gene silencing, Peart and associates (2002) found that, unlike abiotic inducers of cell death, all examined pathogen-derived elicitors required SGT1 for HR induction. Therefore, the result that INF2A-induced necrosis is SGT1 dependent suggests that this protein is likely to induce a typical HR similar to the one induced by the better-characterized INF1 protein and other HR elicitors. However, considering the differences highlighted above, the extent to which INF2 and INF1 induce similar cell death pathways in Nicotiana spp. remains to be determined.

The ability of tobacco, but not $N$. benthamiana, to respond to INF2B could explain differences in resistance to $P$. infestans observed for these two species (Kamoun 2001; Kamoun et al. 1998b). P. infestans strains engineered for INF1-deficiency by antisense gene silencing were found to reach significant levels of biomass and colonization in $N$. benthamiana but not in a number of other Nicotiana spp., including tobacco (Kamoun et al. 1998b). This led to the hypothesis that resistance to $P$. infestans in $N$. benthamiana is triggered mainly by INF1, whereas the resistance reaction observed in tobacco may involve additional elicitor or avirulence factors (Kamoun 2001; Kamoun et al. 1998b). An attractive hypothesis is that the inability of $N$. benthamiana to respond to INF2B, contributes to the difference in response to INF1-deficient strains between these two Nicotiana spp. Future experiments using P. infestans strains silenced for a combination of inf genes should help assess the contribution of the inf 2 genes to avirulence on Nicotiana spp.

The three-dimensional structure of cryptogein, the major basic elicitin (class Ib) of $P$. cryptogea, was determined both as a native protein and complexed with ergosterol (Boissy et al.
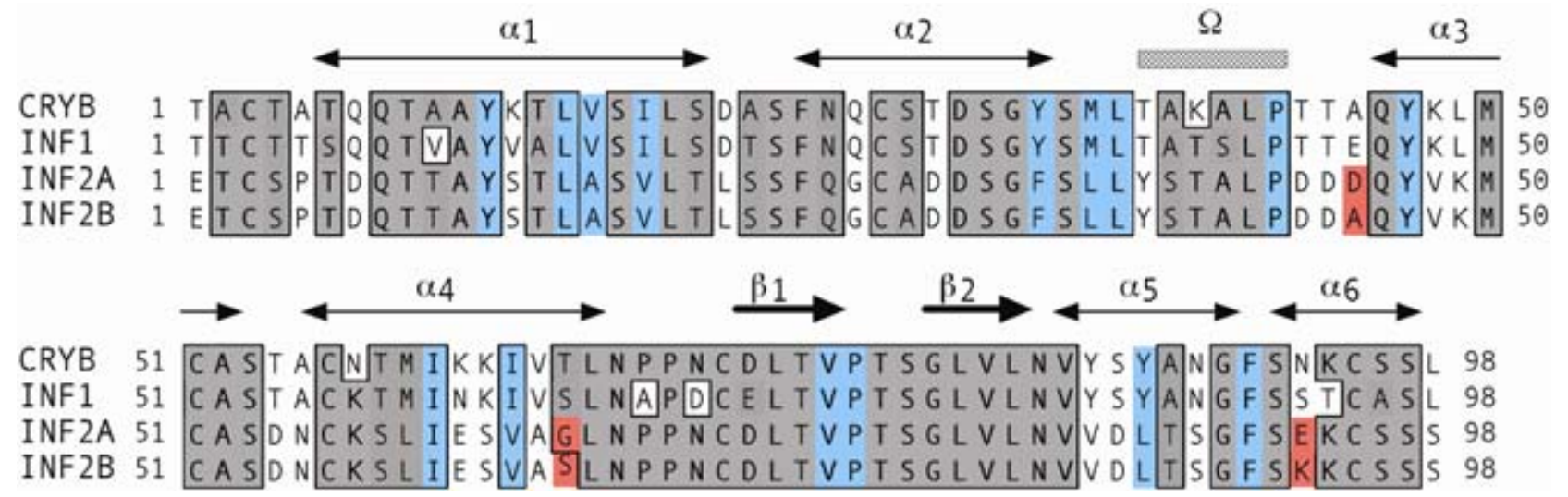

Fig. 9. Multiple alignment of the elicitin domain of selected Phytophthora elicitin and elicitin-like protein highlighting the major structural features. Multiple alignment of elicitin sequences from Phytophthora cryptogea cryptogein (CRY-B) and P. infestans (INF1, INF2A, and INF2B) was conducted using the program CLUSTAL-W (J. D. Thompson, EMBL, Heidelberg, Germany). Identical and similar amino acids are shaded in gray. Residue numbers flank the sequences. The secondary structure elements indicated above the sequences (six $\alpha$ helices, $\Omega$ loop, and two antiparallel $\beta$-sheets) correspond to CRY-B as described in Boissy and associates (1996). Residues in blue were shown by Boissy and associates (1999) to interact with an ergosterol substrate. Residues in red differ between INF2A and INF2B. Residue numbers flank the sequences. 
1996, 1999; Fefeu et al. 1997; Gooley et al. 1998). The main features of the structure of cryptogein, three disulfide bridges, a beak-like motif formed by two antiparallel beta sheets, and an $\Omega$-loop, are likely to be conserved among the $P$. infestans elicitins examined in this study (Fig. 9). Ergosterol binding to cryptogein occurs in a hydrophobic pocket and involves 15 aa residues in cryptogein (Boissy et al. 1999). All these residues are fully conserved among cryptogein, INF1, and other class I elicitins (Fig. 9) (Boissy et al. 1999). However, 6 of these 15 aa are replaced in INF2A and INF2B, including Tyr87 (replaced by Leu) which was shown experimentally to be important in sterol binding and HR induction in cryptogein (Osman et al. 2001b). This marked difference in amino acid composition of the hydrophobic pocket suggests that INF2 may bind different substrates from class I elicitins, perhaps lipid molecules other than sterols. Variation in substrate binding also could explain the difference in elicitor activity between INF2 and class I elicitins, because sterol loading is important for the ability to specifically bind a plasma membrane receptor and induce the HR in tobacco (Osman et al. 2001b).

The differences in HR-inducing activity observed for INF elicitins in $N$. benthamiana and tobacco and the availability of facile functional assays suggest that these genes are ideal for probing structure-function relationships in elicitor proteins. Differences in activity of INF2A and INF2B were observed even though their elicitin domains differ only by 3 aa (Fig. 9). INF2A appeared weaker than INF1 and INF2B in inducing the $\mathrm{HR}$ on tobacco, resulting in lower frequencies of necrosis induction and smaller necrotic lesions when delivered through PVX (Fig. 4; Table 1). On the other hand, INF2B consistently failed to induce the HR on $N$. benthamiana even though it functioned as a potent elicitor in tobacco (Figs. 4 and 5; Table 1). In INF2B, Ser65 is replaced by Gly and Glu93 is replaced by Lys. Both of these residues are located in the $\alpha$ helices and are not implicated in sterol binding. However, they are predicted to be surface exposed and are variable among class I elicitins (Fig. 9). Our results suggest that these residues are important for specific HR activity in $N$. benthamiana and the overall elicitor activity in tobacco. Future domain swapping and amino acid exchange experiments should help determine the role of these residues in elicitin activity.

The Nicotiana genes involved in recognition of elicitins have not yet been identified and, consequently, one can only speculate about the molecular basis of the differences between tobacco and $N$. benthamiana with respect to their response to INF2 elicitins. Elicitin recognition genes in Nicotiana spp. could be members of a variable $R$ gene family, similar to those described in numerous plants to mediate HR induction by pathogen elicitors (Bent 1996; Meyers et al. 1999; Michelmore and Meyers 1998; Staskawicz et al. 1995). The difference observed between tobacco and $N$. benthamiana also indicates that, similar to the phenotypic expression of resistance (Kamoun et al. 1998b), the genetic basis of Nicotiana resistance to P. infestans could be diverse. Perhaps, recognition of species-specific elicitors, such as INF elicitins, by an arsenal of $R$ genes forms the basis of resistance of Nicotiana spp. to P. infestans (Kamoun 2001). Considering this diversity, the P. infestans-Nicotiana spp. pathosystem appears ideal for the dissection and comparative analyses of the molecular basis of nonhost recognition in closely related species.

\section{MATERIALS AND METHODS}

\section{Microbial strains and culture conditions.}

The various $P$. infestans isolates used in this study were described previously (Kamoun et al. 1998a). P. infestans isolates were cultured routinely on rye agar medium supplemented with $2 \%$ sucrose (Caten and Jinks 1968) or in still cultures in the synthetic medium described by Kamoun and associates (1994).

Escherichia coli XL1-Blue and DH5 $\alpha$ were used in most experiments and were routinely grown at $37^{\circ} \mathrm{C}$ in Luria-Bertani media (Sambrook et al. 1989). A. tumefaciens strains EHA105 (Hood et al. 1993) and GV3101 (Holsters et al. 1980) were used. All bacterial DNA transformations were conducted by electroporation.

\section{DNA manipulations and plasmid constructions.}

DNA manipulations and screening of the $\lambda$ EMBL3 library were conducted essentially as described elsewhere (Ausubel et al. 1987; Sambrook et al. 1989). Total DNA of $P$. infestans was isolated from mycelium grown in liquid culture as described previously (Pieterse et al. 1991). Alkaline DNA transfer to Hybond $\mathrm{N}+$ (Amersham, Arlington Heights, IL, U.S.A.) and Southern hybridizations were performed at $65^{\circ} \mathrm{C}$ as described elsewhere (Ausubel et al. 1987; Sambrook et al. 1989). Filters were typically washed at $55^{\circ} \mathrm{C}$ in $0.5 \times \mathrm{SSC}(75 \mathrm{mM} \mathrm{NaCl}$ and $7.5 \mathrm{mM}$ sodium citrate) $(1 \times \mathrm{SSC}$ is $0.15 \mathrm{M} \mathrm{NaCl}$ plus $0.015 \mathrm{M}$ sodium citrate) except for the blot shown in Figure 1, which was washed at low stringency (room temperature in $2 \times$ SSC). Dideoxy chain-termination sequencing was carried out using an AmpliCycle sequencing kit (Perkin-Elmer, Foster City, CA, U.S.A.).

Plasmid pFB60 was obtained by subcloning a gel-purified 1.7-kb HindIII fragment from an inf $2 A$-containing $\lambda$ EMBL3 clone into pBluescript SK- (Stratagene, San Diego, CA, U.S.A.). Sequencing of the full insert of pFB60 was conducted using vector primers as well as a series of internal sequencing primers.

Plasmids pGR106-INF2A and pGR106-INF2B were constructed by cloning PCR-amplified DNA fragments corresponding to a fusion between the signal sequence of the $P R-1 a$ gene of tobacco (Hammond-Kosack et al. 1995) and the sequence of the 98-aa elicitin domain of INF2A and INF2B (Kamoun et al. 1997) into the ClaI site of pGR106 (Lu et al. 2003) using the overlap extension strategy described by Kamoun and associates (1999a). The oligonucleotides used in the PCRs are PVX-F (5'-AATCAATCACAGTGTTGGCTTG C-3') and PR-INF2A (5'-GGCGAGCACGTCTCGGCACGGC AAGAGTGGGATATTAC - $3^{\prime}$ ); and PR-INF2B (5'-CTTGCCG TGCCGAGACGTGCTCGCCCACG-3') and INF2-RSC (5'-G TGGAGCTCATCGATCACGACGAGGAGCACTTCTTGGA$\left.3^{\prime}\right)$. SacI and ClaI restriction sites were introduced in INF2RSC and are underlined. The resulting recombinant plasmids, pGR106-INF2A and pGR106-INF2B, were confirmed by DNA sequencing to have a PRla::inf2 fusion inserted in the sense orientation with regard to the duplicated PVX coat protein promoter. The pGR106-INF1 plasmid was constructed by cloning the PRla::infl fusion sequence (Kamoun et al. 1999a) into the ClaI site of pGR106.

For agroinfiltration experiments, plasmids p35S-INF1 (previously named pInf1) was described earlier (Kamoun et al. 2003). p35S-INF2A and p35S-INF2B were constructed by cloning PCR-amplified DNA fragments corresponding to the $P R-1 a$ ::inf fusions from the respective pGR106-INF constructs as NcoI and SacI fragments into pAvr9 (Van der Hoorn et al. 2000). The oligonucleotides used in the PCRs are PR1-FNCO (5'-GCATCCATGGGATTTGTTCTCTTTTCACAA-3") and INF1-RSAC (5'-GGCGAGCTCTCATAGCGACGCACACGT AG-3') for PRla::infl and INF2-RSC for PRla::inf2. The introduced $\mathrm{NcoI}$ and $\mathrm{SacI}$ restriction sites are underlined. The resulting p35S-INF plasmids were confirmed by DNA sequencing to contain intact PR1a::inf ORFs flanked by the CaMV 35S promoter and the $\Omega$ Tobacco mosaic virus (TMV) 
leader on the $5^{\prime}$ side and the potato proteinase-II terminator region on the $3^{\prime}$ end.

\section{RNA manipulations, Northern blot hybridizations, and RT-PCR analyses.}

Total RNA was isolated from $P$. infestans mycelium using the guanidine hydrochloride extraction method (Logemann et al. 1987), and from N. tabacum using the Trizol RNA extraction protocol following the manufacturer's recommendations (Gibco-BRL, Bethesda, MD, U.S.A.). For Northern blot analyses, 10 to $15 \mu \mathrm{g}$ of total RNA was denatured at $50^{\circ} \mathrm{C}$ in $1 \mathrm{M}$ glyoxal, dimethyl sulfoxide, and $10 \mathrm{mM}$ sodium phosphate, electrophoresed, and transferred to Hybond N+ membranes (Amersham) (Ausubel et al. 1987; Sambrook et al. 1989). Hybridizations were conducted at $65^{\circ} \mathrm{C}$ in $0.5 \mathrm{M}$ sodium phosphate buffer, $7 \%$ sodium dodecyl sulfide, and 1 mM EDTA. Filters were washed at $55^{\circ} \mathrm{C}$ in $0.5 \times \mathrm{SSC}$ for the Phytophthora blots or at $65^{\circ} \mathrm{C}$ in $0.5 \times$ SSC for the plant blots. For the RT-PCR experiments, cDNA derived from a $P$. infestans-tomato time-course experiment was generated as previously described (Tian et al. 2004). Equal amounts of cDNA were subjected to PCR amplification using the following primers: INF1TEV-F (5'-GGGAAATCGATACCAC GTGCACCACCTCGCA-3'), INF1TEV-R (5'-GGGAAATC GATTAGCGACGCACACGTAGACG-3'), INF2TEV-F (5'-G GGAAATCGATGAGACGTGCTCGCCCACGGAC-3'), and INF2A-Rnew (5'-CGCATAGCACTTAACAAGCCGCGGCG G-3'). Primers described by Torto and associates (2002) were used for amplification of ef $2 \alpha$.

\section{Hybridization probes.}

Probes from the inf 2 genes were obtained as gel-purified DNA fragments containing essentially the signal peptide and elicitin domain (amino acids 1 to 126) of the inf $2 A$ and inf $2 B$ cDNA inserts, generated by digestions of the original cDNA plasmids (Kamoun et al. 1997a,b) using appropriate restriction enzymes. A probe from the actA gene from pSTA31 (Unkles et al. 1991) was used as a loading control. The PRla gene probe was generated through PCR amplification of tobacco genomic DNA using the gene-specific primers PR1-tob-F $\left(5^{\prime}\right.$ ATGGGATTTGTTCTCTTTTCACAA-3') and PR1-tob-R (5' GTATGGACTTTCGCCTCTATAATTAC-3'). A probe from the $\alpha$-tubulin gene was amplified from an $N$. otophora cDNA clone using vector primers. Probes were radiolabeled with either $\alpha-32 \mathrm{P}-\mathrm{dATP}$ or $\alpha-32 \mathrm{P}-\mathrm{dCTP}$ using a random primer labeling kit (Gibco-BRL).

In order to obtain probes specific to the various genes, we used the primer extension strategy described by Kamoun and associates (1997b). Single-stranded, radiolabeled probe complementary to the $3^{\prime}$ end untranslated region of the infl mRNA was generated by extending primer INF2-F1 (Kamoun et al. 1997b) from the gel-purified infl insert from pFB7. Singlestranded, radiolabeled probes complementary to the $3^{\prime}$ end untranslated region of the inf $2 A$, and inf $2 B$ mRNAs, were generated by extending primer INF2-F2 (5'-CCACCGCGGCTT GTTAAG-3') from XhoI-digested pFB5 and pFB24, respecttively. The sequence corresponding to the TAA stop codon of the inf $2 A$ and inf $2 B$ ORFs is underlined. The labeling reactions were performed as previously described (Kamoun et al. 1997b).

\section{PVX agroinfection assays.}

Tobacco (cv. Xanthi) and N. benthamiana plants with fully expanded leaves were used for the agroinfection assays. Plants were cultured and maintained in a greenhouse with an ambient temperature of 22 to $25^{\circ} \mathrm{C}$ and high light intensity. Inoculations were performed by dipping a wooden sterile toothpick in a recombinant A. tumefaciens GV3101 (pGR106-INF) colony grown on solid agar medium and wounding each leaf twice around the main vein. An excess of bacteria was used for the inoculations. Local necrotic symptoms were scored daily and typically started developing within 5 to 7 days after inoculation.

All constructs were re-evaluated on young $N$. benthamiana plants at approximately the three-to four-leaf stage (approximately 3 weeks old). Inoculations then were performed on two lower leaves by wounding each leaf twice around the main vein and near the base of the leaf with the A. tumefaciens strain. Mosaic, local, and systemic necrotic symptoms were scored daily and typically started developing within 5 to 7 days after inoculation.

\section{Agroinfiltration assays.}

Recombinant $A$. tumefaciens strains containing the various binary plasmids were prepared for agroinfiltration as described previously (Kapila et al. 1997; Van der Hoorn et al. 2000). Cultures were infiltrated into young and fully expanded leaves. Most p35S-INF1 and p35S-INF2 infiltrations were conducted side by side and repeated at least three times.

\section{GUS assays.}

We used a transgenic tobacco line (cv. Samsun NN) carrying a $B g l 2:: G U S$ reporter construct. The selected line (gglb-12333), generated by Livne et al. (1997) to express a chimeric gglb50 promoter (basic $\beta$-1,3-glucanase, GenBank accession number X53600) fused to the GUS reporter gene, contains the gglb50 promoter region between positions $-1,233$ and +19 . Histochemical GUS staining was performed using $2 \mathrm{mM} \mathrm{5-}$ bromo-4-chloro-3-indolyl- $\beta$-D-glucuronic acid (X-Gluc) (Rose Scientific, Edmonton Alberta, Canada) as described previously by Huitema and associates (2003).

\section{TRV-silencing experiments.}

Agrobacterium strains carrying pBINTRA6 (RNA 1 vector), pTV00 (RNA 2 vector), and pTV00:SGT1 (Peart et al. 2002; Ratcliff et al. 2001) were prepared for agroinfiltration as described above, and mixed in a 2:1 RNA 1/RNA 2 ratio. The SGT1 insert corresponds to the NbSGT1.1 gene (GenBank accession number AF516180). Mixed cultures were incubated for at least $2 \mathrm{~h}$ before infiltration. The youngest fully expanded leaves of $N$. benthamiana plants (five-leaf stage) were infiltrated with the Agrobacterium suspensions using needleless syringes. Challenge inoculations using agroinfiltration or PVX agroinfection assays were started 3 weeks after TRV inoculation and performed as described above.

\section{ACKNOWLEDGMENTS}

This work was supported by a Netherlands Technology Foundation (STW) grant coordinated by the Life Sciences Foundation (SLW) WBI.3846, National Science Foundation Plant Genome Research Program grant DBI-0211659, and state and federal funds appropriated to the Ohio Agricultural Research and Development Center, the Ohio State University. We are grateful to K. de Groot, S. Dong, D. Kinney, and H. Lindqvist for expert technical assistance; P. van West and E. Gaulin for useful comments; and I. Malcuit and D. Baulcombe for useful advice and for providing the PVX and TRV vectors.

\section{LITERATURE CITED}

Ausubel, F. M., Brent, R., Kingston, R. E., Moore, D. D., Seidman, J. G., Smith, J. A., and Struhl, K. 1987. Current Protocols in Molecular Biology. J. Wiley \& Sons, New York.

Bateman, A., Birney, E., Cerruti, L., Durbin, R., Etwiller, L., Eddy, S.R., Griffiths-Jones, S., Howe, K. L., Marshall, M., and Sonnhammer, E. L. L. 2002. The Pfam protein families database. Nucleic Acids Res. 30:276-280. 
Bent, A. 1996. Plant disease resistance genes: Function meets structure. Plant Cell 8:1757-1771.

Birch, P. R. J., and Whisson, S. 2001. Phytophthora infestans enters the genomics era. Mol. Plant Pathol. 2:257-263.

Boissy, G., de La Fortelle, E., Kahn, R., Huet, J. C., Bricogne, G., Pernollet, J. C., and Brunie, S. 1996. Crystal structure of a fungal elicitor secreted by Phytophthora cryptogea, a member of a novel class of plant necrotic proteins. Structure 4:1429-1439.

Boissy, G., O’Donohue, M., Gaudemer, O., Perez, V., Pernollet, J. C., and Brunie, S. 1999. The 2.1 A structure of an elicitin-ergosterol complex: A recent addition to the Sterol Carrier Protein family. Protein Sci. 8:11911199.

Caten, C. E., and Jinks, J. L. 1968. Spontaneous variability of single isolates of Phytophthora infestans. I. Cultural variation. Can. J. Bot. 46:329-347.

Dangl, J. L., Dietrich, R. A., and Richberg, M. H. 1996. Death don't have no mercy: Cell death programs in plant-microbe interactions. Plant Cell 8:1793-1807.

Dangl, J. L., and Jones, J. D. 2001. Plant pathogens and integrated defence responses to infection. Nature 411:826-833.

Fabritius, A. L., Cvitanich, C., and Judelson, H. S. 2002. Stage-specific gene expression during sexual development in Phytophthora infestans. Mol. Microbiol. 45:1057-1066.

Fefeu, S., Bouaziz, S., Huet, J. C., Pernollet, J. C., and Guittet, E. 1997. Three-dimensional solution structure of beta cryptogein, a beta elicitin secreted by a phytopathogenic fungus Phytophthora cryptogea. Protein Sci. 6:2279-2284.

Fry, W. E., and Goodwin, S. B. 1997a. Re-emergence of potato and tomato late blight in the United States. Plant Dis. 81:1349-1357.

Fry, W. E., and Goodwin, S. B. 1997b. Resurgence of the Irish potato famine fungus. Bioscience 47:363-371.

Gooley, P. R., Keniry, M. A., Dimitrov, R. A., Marsh, D. E., Keizer, D. W. Gayler, K. R., and Grant, B. R. 1998. The NMR solution structure and characterization of $\mathrm{pH}$ dependent chemical shifts of the beta-elicitin, cryptogein. J. Biomol. NMR 12:523-534.

Hammond-Kosack, K. E., Staskawicz, B. J., Jones, J. D. G., and Baulcombe, D. C. 1995. Functional expression of a fungal avirulence gene from a modified potato virus X genome. Mol. Plant-Microbe Interact. 8:181185

Heath, M. C. 2000. Nonhost resistance and nonspecific plant defenses. Curr. Opin. Plant Biol. 3:315-319.

Hendrix, J. W. 1970. Sterols in growth and reproduction of fungi. Annu. Rev. Phytopathol. 8:111-130.

Holsters, M., Silva, B., Van Vliet, F., Genetello, C., De Block, M., Dhaese, P., Depicker, A., Inze, D., Engler, G., Villaroel, R., Van Montagu, M., and Schell, J. 1980. The functional organization of the nopaline A. tumefaciens plasmid pTiC58. Plasmid 3:212-230.

Hood, E. E., Gelvin, S. B., Melchers, L. S., and Hoekema, A. 1993. New Agrobacterium helper plasmids for gene transfer to plants. Transgenic Res. 2:208-218.

Huitema, E., Bos, J. I. B., Tian, M., Win, J., Waugh, M. E., and Kamoun, S. 2004. Linking sequence to phenotype in Phytophthora-plant interactions. Trends Microbiol. 12:193-200.

Huitema, E., Vleeshouwers, V. G. A. A., Francis, D. M., and Kamoun, S 2003. Active defence responses associated with non-host resistance of Arabidopsis thaliana to the oomycete pathogen Phytophthora infestans. Mol. Plant Pathol. 4:487-500.

Jentoft, N. 1990. Why are proteins $O$-glycosylated? Trends Biochem. Sci. 15:291-294

Kamoun, S. 2001. Nonhost resistance to Phytophthora: Novel prospects for a classical problem. Curr. Opin. Plant Biol. 4:295-300.

Kamoun, S. 2003. Molecular genetics of pathogenic oomycetes. Eukaryot. Cell 2:191-199.

Kamoun, S., Hamada, W., and Huitema, E. 2003. Agrosuppression: A bioassay for the hypersensitive response suited to high-throughput screening. Mol. Plant-Microbe Interact. 16:7-13.

Kamoun, S., Honee, G., Weide, R., Lauge, R., Kooman-Gersmann, M., de Groot, K., Govers, F., and de Wit, P. J. G. M. 1999a. The fungal gene Avr 9 and the oomycete gene infl confer avirulence to potato virus $\mathrm{X}$ on tobacco. Mol. Plant-Microbe Interact. 12:459-462.

Kamoun, S., Hraber, P., Sobral, B., Nuss, D., and Govers, F. 1999b. Initial assessment of gene diversity for the oomycete pathogen Phytophthora infestans based on expressed sequences. Fungal Genet. Biol. 28:94-106.

Kamoun, S., Huitema, E., and Vleeshouwers, V. G. A. A. 1999c. Resistance to oomycetes: A general role for the hypersensitive response? Trends Plant Sci. 4:196-200.

Kamoun, S., Lindqvist, H., and Govers, F. 1997a. A novel class of elicitinlike genes from Phytophthora infestans. Mol. Plant-Microbe Interact. 10:1028-1030.

Kamoun, S., van der Lee, T., van den Berg, G., de Groot, K. E., and Govers, F. 1998a. Loss of production of the elicitor protein INF1 in the clonal lineage US-1 of Phytophthora infestans. Phytopathology $88: 1315-1323$

Kamoun, S., van West, P., de Jong, A. J., de Groot, K., Vleeshouwers, V., and Govers, F. 1997b. A gene encoding a protein elicitor of Phytoph thora infestans is down-regulated during infection of potato. Mol. Plant-Microbe Interact. 10:13-20.

Kamoun, S., van West, P., Vleeshouwers, V. G., de Groot, K. E., and Govers, F. 1998b. Resistance of Nicotiana benthamiana to Phytophthora infestans is mediated by the recognition of the elicitor protein INF1. Plant Cell 10:1413-1426.

Kamoun, S., Young, M., Forster, H., Coffey, M. D., and Tyler, B. M. 1994. Potential role of elicitins in the interaction between Phytophthora: Species and tobacco. Appl. Environ. Microbiol. 60:1593-1598.

Kamoun, S., Young, M., Glascock, C., and Tyler, B. M. 1993. Extracellular protein elicitors from Phytophthora: Host-specificity and induction of resistance to fungal and bacterial phytopathogens. Mol. Plant-Microbe Interact. 6:15-25

Kanzaki, H., Saitoh, H., Ito, A., Fujisawa, S., Kamoun, S., Katou, S., Yoshioka, Y., and Terauchi, R. 2003. Cytosolic HSP90 and HSP70 are essential components of INF1-mediated hypersensitive response and non-host resistance to Pseudomonas cichorii in Nicotiana benthamiana. Mol. Plant Pathol. 4:383-391.

Kapila, J., de Rycke, R., Van Montagu, M., and Angenon, G. 1997. An Agrobacterium-mediated transient gene expression system for intact leaves. Plant Sci. 122:101-108.

Livne, B., Faktor, O., Zeitoune, S., Edelbaum, O., and Sela, I. 1997. TMVinduced expression of tobacco $\beta$-glucanase promoter activity is mediated by a single, inverted, GCC motif. Plant Sci. 130:159-169.

Logemann, J., Schell, J., and Willmitzer, L. 1987. Improved method for isolation of RNA from plant tissue. Anal. Biochem. 163:16-20.

Lu, R., Malcuit, I., Moffett, P., Ruiz, M. T., Peart, J., Wu, A. J., Rathjen, J. P., Bendahmane, A., Day, L., and Baulcombe, D. C. 2003. High throughput virus-induced gene silencing implicates heat shock protein 90 in plant disease resistance. EMBO (Eur. Mol. Biol. Organ.) J. 22:5690-5699.

McLeod, A., Smart, C. D., and Fry, W. E. 2004. Core promoter structure in the oomycete Phytophthora infestans. Eukaryot. Cell 3:91-99.

Meyers, B. C., Dickerman, A. W., Michelmore, R. W., Sivaramakrishnan, S., Sobral, B. W., and Young, N. D. 1999. Plant disease resistance genes encode members of an ancient and diverse protein family within the nucleotide-binding superfamily. Plant J. 20:317-332.

Michelmore, R. W., and Meyers, B. C. 1998. Clusters of resistance genes in plants evolve by divergent selection and a birth-and-death process. Genome Res. 8:1113-1130.

Mikes, V., Milat, M. L., Ponchet, M., Panabieres, F., Ricci, P., and Blein, J. P. 1998. Elicitins, proteinaceous elicitors of plant defense, are a new class of sterol carrier proteins. Biochem. Biophys. Res. Commun. 245:133-139.

Mikes, V., Milat, M. L., Ponchet, M., Ricci, P., and Blein, J. P. 1997. The fungal elicitor cryptogein is a sterol carrier protein. FEBS (Fed. Eur. Biol. Soc.) Lett. 416:190-192.

Mulder, N. J., Apweiler, R., Attwood, T. K., Bairoch, A., Barrell, D., Bateman, A., Binns, D., Biswas, M., Bradley, P., Bork, P., Bucher, P., Copley, R. R., Courcelle, E., Das, U., Durbin, R., Falquet, L., Fleischmann, W., Griffiths-Jones, S., Haft, D., Harte, N., Hulo, N., Kahn, D., Kanapin, A., Krestyaninova, M., Lopez, R., Letunic, I., Lonsdale, D., Silventoinen, V., Orchard, S. E., Pagni, M., Peyruc, D., Ponting, C. P., Selengut, J. D., Servant, F., Sigrist, C. J. A., Vaughan, R. and Zdobnov, E. M. 2003. The InterPro Database, 2003 brings increased coverage and new features. Nucleic Acids Res. 31:315-318.

Nespoulous, C., Gaudemer, O., Huet, J. C., and Pernollet, J. C. 1999. Characterization of elicitin-like phospholipases isolated from Phytophthora capsici culture filtrate. FEBS (Fed. Eur. Biol. Soc.) Lett. 452:400406.

Osman, H., Mikes, V., Milat, M. L., Ponchet, M., Marion, D., Prange, T. Maume, B. F., Vauthrin, S., and Blein, J. P. 2001a. Fatty acids bind to the fungal elicitor cryptogein and compete with sterols. FEBS (Fed. Eur. Biol. Soc.) Lett. 489:55-58.

Osman, H., Vauthrin, S., Mikes, V., Milat, M. L., Panabieres, F., Marais, A., Brunie, S., Maume, B., Ponchet, M., and Blein, J. P. 2001b. Mediation of elicitin activity on tobacco is assumed by elicitin-sterol complexes. Mol. Biol. Cell. 12:2825-2834.

Peart, J. R., Lu, R., Sadanandom, A., Malcuit, I., Moffett, P., Brice, D. C. Schauser, L., Jaggard, D. A., Xiao. S., Coleman, M. J., Dow, M., Jones, J. D., Shirasu, K., and Baulcombe, D. C. 2002. Ubiquitin ligase-associated protein SGT1 is required for host and nonhost disease resistance in plants. Proc. Natl. Acad. Sci. U.S.A. 6:10865-10869.

Pieterse, C. M. J., Riach, M. R., Bleker, T., van den Berg Velthuis, G. C. M., and Govers, F. 1993. Isolation of putative pathogenicity genes of the potato late blight fungus Phytophthora infestans by differential screening of a genomic library. Physiol. Mol. Plant Pathol. 43:69-79. 
Pieterse, C. M. J., Risseeuw, E. P., and Davidse, L. C. 1991. An in planta induced gene of Phytophthora infestans codes for ubiquitin. Plant Mol. Biol. 17:799-811.

Ponchet, M., Panabieres, F., Milat, M.-L., Mikes, V., Montillet, J.-L., Suty, L., Triantaphylides, C., Tirilly, Y., and Blein, J.-P. 1999. Are elicitins cryptograms in plant-Oomycete communications? Cell. Mol. Life Sci. 56:1020-1047.

Qutob, D., Hraber, P. T., Sobral, B. W., and Gijzen, M. 2000. Comparative analysis of expressed sequences in Phytophthora sojae. Plant Physiol. 123:243-254

Qutob, D., Huitema, E., Gijzen, M., and Kamoun, S. 2003. Variation in structure and activity among elicitins from Phytophthora sojae. Mol. Plant Pathol. 4:119-124.

Qutob, D., Kamoun, S., and Gijzen, M. 2002. Expression of a Phytophthora sojae necrosis-inducing protein occurs during transition from biotrophy to necrotrophy. Plant J. 32:361-373.

Ratcliff, F., Martin-Hernandez, A. M., and Baulcombe, D. C. 2001. Tobacco rattle virus as a vector for analysis of gene function by silencing. Plant J. 25:237-245.

Ricci, P., Bonnet, P., Huet, J.-C., Sallantin, M., Beauvais-Cante, F., Bruneteau, M., Billard, V., Michel, G., and Pernollet, J.-C. 1989. Structure and activity of proteins from pathogenic fungi Phytophthora eliciting necrosis and acquired resistance in tobacco. Eur. J. Biochem. 183:555-563

Sambrook, J., Fritsch, E. F., and Maniatis, T. 1989. Molecular Cloning: A Laboratory Manual, 2nd ed. Cold Spring Harbor Laboratory Press, Cold Spring Harbor, NY.

Sasabe, M., Takeuchi, K., Kamoun, S., Ichinose, Y., Govers, F., Toyoda, K., Shiraishi, T., and Yamada, T. 2000. Independent pathways leading to apoptotic cell death, oxidative burst and defense gene expression in response to elicitin in tobacco cell suspension culture. Eur. J. Biochem. 267:5005-5013.

Schiermeier, Q. 2001. Russia needs help to fend off potato famine, researchers warn. Nature 410:1011.

Sharma, P. C., Ito, A., Shimizu, T., Terauchi, R., Kamoun, S., and Saitoh, H. 2003. Virus-induced silencing of WIPK and SIPK genes in Nicotiana benthamiana cause reduced resistance against an incompatible bacterial pathogen but no effect on HR triggered by INF1. Mol. Genet. Genom 269:583-591.

Shattock, R. C. 2002. Phytophthora infestans: Populations, pathogenicity and phenylamides. Pest Manage. Sci. 58:944-950.
Shirasu, K., and Schulze-Lefert, P. 2003. Complex formation, promiscuity and multi-functionality: Protein interactions in disease-resistance pathways. Trends Plant Sci. 8:252-258.

Smart, C. D., and Fry, W. E. 2001. Invasions by the late blight pathogen: Renewed sex and enhanced fitness. Biol. Invas. 3:235-243.

Staskawicz, B. J., Ausubel, F. M., Baker, B. J., Ellis, J. G., and Jones, J. D. G. 1995. Molecular genetics of plant disease resistance. Science 268:661-667.

Tian, M., Huitema, E., da Cunha, L., Torto-Alalibo, T., and Kamoun, S. 2004. A Kazal-like extracellular serine protease inhibitor from Phytophthora infestans targets the tomato pathogenesis-related protease P69B. J. Biol. Chem. 279:26370-26377.

Tör, M., Yemm, A., and Holub, E. 2003. The role of proteolysis in $R$ gene mediated defence in plants. Mol. Plant Pathol. 4:287-296.

Torto, T., Li, S., Styer, A., Huitema, E., Testa, A., Gow, N. A. R., van West, P., and Kamoun, S. 2003. EST mining and functional expression assays identify extracellular effector proteins from Phytophthora. Genome Res. 13:1675-1685.

Torto, T., Rauser, L., and Kamoun, S. 2002. The pipg1 gene of the oomycete Phytophthora infestans encodes a fungal-like endopolygalacturonase. Curr. Genet. 40:385-390.

Unkles, S. E., Moon, R. P., Hawkins, A. R., Duncan, J. M., and Kinghorn, J. R. 1991. Actin in the oomycetous fungus Phytophthora infestans is the product of several genes. Gene 100:105-112.

Van der Hoorn, R. A., Laurent, F., Roth, R., and De Wit, P. J. G. M. 2000. Agroinfiltration is a versatile tool that facilitates comparative analyses of Avr9/Cf-9-induced and Avr4/Cf-4-induced necrosis. Mol. PlantMicrobe Interact. 13:439-446.

van West, P., Kamoun, S., van't Klooster, J. W., and Govers, F. 1999. Internuclear gene silencing in Phytophthora. Mol. Cell 3:339-348.

Vauthrin, S., Mikes, V., Milat, M. L., Ponchet, M., Maume, B., Osman, H., and Blein, J. P. 1999. Elicitins trap and transfer sterols from micelles, liposomes and plant plasma membranes. Biochim. Biophys. Acta 1419:335-342.

\section{AUTHOR-RECOMMENDED INTERNET RESOURCE}

The Sainsbury Lab at the John Innes Center, D. Baulcomb's VIGS protocol webpage:

www.jic.bbsrc.ac.uk/Sainsbury-Lab/dcb/Services/vigsprotocol.htm 